\title{
Observation: Leafy spurge control in western prairie fringed orchid habitat
}

\author{
DONALD R. KIRBY, RODNEY G. LYM, JOHN J. STERLING, AND CAROLYN HULL SIEG
}

Authors are Professor, Animal and Range Sciences Department, North Dakota State University, Fargo, N.D. 58105; Professor, Plant Sciences Department, North Dakota State University, Fargo, N.D. 58105; Research Assistant, Animal and Range Sciences Department, North Dakota State University, Fargo, N.D. 58105; and Research Plant Ecologist, USDA Forest Service Rocky Mountain Research Station, 2500 S. Pine Knoll Drive, Flagstaff, Ariz. 86001.

\section{Abstract}

The western prairie fringed orchid (Platanthera praeclara Sheviak and Bowles) is a threatened species of the tallgrass prairie. Invasion by leafy spurge (Euphorbia esula L.) is a serious threat to western prairie fringed orchid habitat. The objectives of this study were to develop a herbicide treatment to control leafy spurge while sustaining western prairie fringed orchid populations and to evaluate the soil seedbank composition of leafy spurge-infested sites to guide long-term management strategies. Quinclorac (3,7-dichloro-8-quinolinecarboxylic acid), imazapic $\{( \pm)-2-[4,5-d i h y d r o-4-m e t h y l-4-(1-m e t h y l e t h y l)-5-o x o-1 H$-imidazol-2=yl]-5-methyl-3-pyridinecarboxylic acid\}, and glyphosate [N-(phosphonomethyl)glycine] plus 2,4-D (2,4-dichlorophenoxy acetic acid) were applied in the fall for 2 consecutive years, and changes in leafy spurge cover, density, yield, and herbaceous yield were assessed. In a separate study, quinclorac, imazapic, and glyphosate plus 2,4-D were each fall-applied to 12 western prairie fringed orchids and assessed for reoccurrence and density of orchids 1-year after treatment. Quinclorac and imazapic, but not glyphosate plus 2,4-D, reduced leafy spurge cover, density, and yield without causing deleterious effects to associated native herbaceous cover and yields. Western prairie fringed orchid reoccurrence and density were unaffected by any herbicide 1 year after treatment. Soil cores were removed in spring and fall following the first year herbicide treatment, washed and placed in trays. Seedlings were allowed to germinate for 16 weeks in the greenhouse. Over 50 plant species were identified in the soil seedbank, of which approximately $60 \%$ were early seral species indicative of disturbance. Given the dominance of leafy spurge in the seed bank, a long-term management program to control this noxious species is warranted. Although these results are promising, longerterm studies need be conducted to ensure that repeated herbicide treatments do not harm the western prairie fringed orchid.

Key Words: invasive species, herbicides, range improvement, soil seedbank

Leafy spurge (Euphorbia esula L.) invasion in southeastern North Dakota is a threat to the western prairie fringed orchid (Platanthera praeclara Sheviak and Bowles), a federally listed threatened plant species (U.S. Fish and Wildlife Service 1989, Wolken et al. 2001). Leafy spurge is an introduced perennial nox-

Manuscript accepted 4 Nov. 02.

\section{Resumen}

"Western prairie fringed orchid" (Platanthera praeclara Sheviak and Bowles) es una especie amenazada en los pastizales altos. La invasión de "Leafy spurge" (Euphorbia esula L.) Es una seria amenaza para el hábitat del "Western prairie fringed orchid". Los objetivos de este estudio fueron desarrollar un tratamiento de herbicida para controlar el "Leafy spurge" mientras se mantienen poblaciones de "Western prairie fringed orchid" y evaluar la composición del banco de semillas del suelo de sitios infestados con "Leafy spurge" para guiar estrategias de manejo a largo plazo. En el otoño de 2 años consecutivos se aplicaron los siguientes herbicidas: Quinclorac (ácido 3,7-dicloro-8quinolinecarboxilico $)$, Imazapic $\{( \pm)$-2-[ácido 4,5-dihidro-4metil-4-(I-metiletil)-5-oxo-IH-imidazo1-2=y1]-5-metil-3piridinecarboxilico\} y Glifosato [N-(Fosfonometil)glicine] mas 2,4-D (ácido 2,4- diclorofenoxiacético) y se evaluaron los cambios de cobertura, densidad, rendimiento de "Leafy spurge" y el rendimiento de herbáceas. En un estudio separado el Quinclorac, Imazapic, and Glifosato mas 2,4-D fueron aplicados cada otoño a 12 "Western prairie fringed orchids" y se evaluó la reocurrencia y densidad de las orquídeas 1 año después de aplicar el tratamiento. El Quinclorac e imazapic, pero no el glifosato mas 2,4-D, redujeron la cobertura, densidad y rendimiento del "Leafy spurge" sin causar efectos perjudiciales en la cobertura y rendimiento de las herbáceas nativas asociadas. Después de 1 año de aplicados los tratamientos ninguno de ellos afectó la reocurrencia y densidad de "Western prairie fringed orchid". Muestras de suelo fueron removidas en la primavera y otoño siguientes del primer año de tratamiento de herbicida y fueron lavadas y colocadas en charolas. Se permitió que las plántulas germinaran en el invernadero durante un periodo de 16 semanas. Mas de 50 especies de plantas se identificaron en el banco de semilla del suelo, de las cuales aproximadamente el $60 \%$ fueron especies serales indicativas de disturbio. Dada la dominancia de "Leafy spurge" en el banco de semilla, se garantiza un programa de manejo a largo plazo para controlar esta especie nociva. Aunque estos resultados son promisorios, se necesita conducir estudios a largo plazo para asegurar que los tratamientos repetidos de herbicidas no dañan el "Western prairie fringed orchid".

ious weed that infests approximately 0.5 million ha in North Dakota (Lym et al. 2000). It is a long-lived plant native to Europe and Asia that spreads prolifically by seed and adventitious buds on roots and crowns (Dunn 1979). Leafy spurge can tolerate a variety of environmental conditions and habitats from rocky 
buttes to sandy shorelines and is difficult to control. Plant communities where leafy spurge dominates often have reduced frequency and density of associated native herbaceous species (Selleck et al. 1962). Leafy spurge has been detected in habitats supporting the western prairie fringed orchid in North Dakota (Sieg and Bjugstad 1994) and Minnesota (Winter 1994), and continued expansion of this invasive species could present a serious threat to the western prairie fringed orchid (U.S. Fish and Wildlife Service 1996).

The original range of the western prairie fringed orchid extended from Manitoba, Canada through North Dakota and Minnesota to Oklahoma and Missouri (Bowles 1983). Western prairie fringed orchid populations, once widespread throughout tallgrass prairies, are now limited to isolated prairie remnants due to habitat loss. One of the largest populations remaining occurs on the Sheyenne National Grassland, a 28,750 ha federally managed tallgrass prairie in southeastern North Dakota. Leafy spurge infests approximately 15 to $20 \%$ of the Sheyenne National Grassland. If leafy spurge is allowed to continue to spread into western prairie fringed orchid habitat, it could outcompete the western prairie fringed orchid; yet, non-selective control methods also pose a potential threat to the western prairie fringed orchid (U.S. Fish and Wildlife Service 1996).

Leafy spurge has been controlled with a variety of herbicides (Lym 1998). However, herbicides cannot be used in areas where the western prairie fringed orchid is located due to its status as a threatened species. The biological control agent Aphthona spp. flea beetles have become widely established and can greatly reduce leafy spurge infestations, but Aphthona spp. generally do not survive well in the sandy, mesic habitat of the western prairie fringed orchid (Lym 1998, Mundal et al. 2002).

Traditionally treatments of picloram (4amino-3,5,6-trichloro-2-pyridinecarboxylic acid) plus 2,4-D (2,4-dichlorophenoxy acetic acid) either spring or fall applied have been used to control leafy spurge in the region (Lym 1998). However, picloram cannot be used in areas with a high water table, which often includes habitats that support the western prairie fringed orchid. Herbicides that have potential to control leafy spurge without harming the western prairie fringed orchid include imazapic $\{( \pm)-2$ [4,5-dihydro-4-methyl-4-(1-methylethyl)5-oxo- $1 H$-imidazol-2=yl] $-5-$ methyl-3- pyridinecarboxylic acid \} and quinclorac (3,7-dichloro-8-quinolinecarboxylic acid), which provide good to excellent leafy spurge control with little or no injury to other desirable broadleaf and grass species (Kuehl and Lym 1997, Markle and Lym 2001). Also, glyphosate [N-(phosphonomethyl)glycine] plus 2,4-D can be used for leafy spurge control in areas with a high water table such as the Sheyenne National Grassland, and has no soil residual (Lym 1998).

A herbicide demonstration trial on the Sheyenne National Grassland in the early 1990 's indicated that herbicides could be used to control leafy spurge and allow the western prairie fringed orchid to reestablish; however, after 2 years the trial had to be discontinued because the threatened western prairie fringed orchid appeared in some plots treated with fall-applied herbicides. Therefore, the present study was initiated with the objectives of 1) evaluate 3 fall-applied herbicides for leafy spurge control, 2) assess the impact of these herbicides on reappearance and density of the western prairie fringed orchid and production of other species, and 3) quantify the soil seedbank composition to determine what plant species are present to revegetate the site following control of leafy spurge.

\section{Materials and Methods}

\section{Study Area}

The study was conducted on the Sheyenne National Grassland $\left(46^{\circ} 28^{\prime} \mathrm{N}\right.$ latitude, $97^{\circ} 16^{\prime} \mathrm{W}$ longitude) approximately $80 \mathrm{~km}$ southwest of Fargo, N.D. The Sheyenne National Grassland is part of a geologic unit known as the Sheyenne River Delta formed approximately 10,000 to 12,000 years ago. The Sheyenne National Grassland consists of stabilized sandy dune-like topography with well drained hummocks (uplands) and subirrigated swales (lowlands). The soils of the study were Serden (Mixed, frigid typic Udipsamments) and Maddock-Hecla (Sandy, mixed, frigid Entic HapludollsSandy, mixed, frigid Oxyaquic Hapludolls) loamy fine sands, which are well drained and susceptible to wind erosion.

Average annual precipitation for the area is $48 \mathrm{~cm}$ with approximately $70 \%$ received during the growing season May-September. Precipitation received during this study (1997 and 1998) was 60 and $78 \mathrm{~cm}$, respectively, which was above the long-term average.

The vegetation of the Sheyenne
National Grassland is complex consisting of at least 12 distinct plant communities (Seiler and Barker 1985). The major plant communities present on the study site were sedge meadow, tallgrass prairie and mixed grass prairie. The sedge meadow was dominated by various sedges (Carex spp.), bluegrasses (Poa spp.), reed grasses (Calamogrostis spp.), switchgrass (Panicum virgatum L.), and willows (Salix spp.), which invaded the site. The tallgrass prairie was dominated by big bluestem (Andropogon gerardii Vitman), little bluestem (Schizachyrium scoparium Michx.), switchgrass, and Kentucky bluegrass (Poa pratensis L.). The mixed grass prairie was dominated by needlegrass (Stipa spp.), blue grama [Bouteloua gracilis (H.B.K.) Lag ex. Griffiths], Kentucky bluegrass, and the introduced leafy spurge.

\section{Leafy Spurge Herbicide Trial}

Fall-applied herbicides that generally control leafy spurge and can be used in the mesic habitat that supports the western prairie fringed orchid were evaluated. Treatments included glyphosate plus 2,4$\mathrm{D}$ at 220 plus 330 and 440 plus $670 \mathrm{~g}$ ae $\mathrm{ha}^{-1}$, imazapic at 70 and $140 \mathrm{~g}^{2} \mathrm{ha}^{-1}$ plus methylated seed oil ${ }^{1}$ at 2.3 liters $^{-1} a^{-1}$ plus urea-ammonium nitrate fertilizer $(28 \% \mathrm{~N})$ at 2.3 liters ha ${ }^{-1}$, and quinclorac at 880 and $1100 \mathrm{~g}$ ae ha $\mathrm{h}^{-1}$ plus methylated seed oil ${ }^{2}$ at 2.3 liters $\mathrm{ha}^{-1}$. Herbicides were applied with a hand-held $\mathrm{CO}_{2}$-pressurized sprayer with four, 8001 flat-fan nozzles ${ }^{3}$ delivering 80 liters ha $\mathrm{h}^{-1}$ at $280 \mathrm{kPa}$. The treatments were applied 2 consecutive years in mid-September in 1997 and 1998, to mature leafy spurge with 3 to $10 \mathrm{~cm}$ of fall regrowth on stems and branches. The experimental design was a randomized complete block, replicated 4 times, with 3by $9.1-\mathrm{m}$ plots.

Vegetation cover and density were estimated using 6 , randomly placed $0.1-\mathrm{m}^{2}$ quadrats (Daubenmire 1959) in the summer of 1998, 10 months after the first treatment, with the final evaluations made in 1999, 22 months after the first treatment. Percent canopy cover was visually estimated for litter, leafy spurge, forb, grass, shrub, and bare ground. Individual plants were identified and counted by species to determine density in each treatment.

Herbaceous yield was estimated in August 1999 (23 months after the first

\footnotetext{
${ }^{1}$ Methylated seed oil was SUN-IT II by AGSCO, $116012^{\text {th }}$ St. NE, Grand Forks, N.D. 58201.

${ }^{2}$ Methylated seed oil was SCOIL by AGSCO, 1160 $12^{\text {th }}$ St. NE, Grand Forks, N.D. 58201.

${ }^{3}$ TeeJet, Spraying Systems Co., P.O. Box 7900 Wheaton Ill. 60189.
} 
treatment) by clipping five, $0.25-\mathrm{m}^{2}$ quadrats and hand separating to leafy spurge, grass, grass-like, native forb, and other categories. Quadrats were randomly located on transects placed centrally through the length of each plot. Yield samples from each plot were placed in individual bags, dried at $45^{\circ} \mathrm{C}$ for 7 days, and weighed.

Herbicide efficacy was tested using the general factorial analysis of variance (ANOVA) for a randomized complete block design. Herbicide control of leafy spurge was evaluated along with injury to other species (SPSS 1994). Means were separated using the Duncan's Multiple Range Test and considered significant at $\mathrm{P}$ $<0.05$.

\section{Herbicide Effect on Western Prairie Fringed Orchid Reoccurrence}

Authorization to treat up to 96 western prairie fringed orchids [permit PRT704930 (subpermit sp 98-41.99] was obtained from the U.S. Fish and Wildlife Service. Herbicides were the same as described in the first study, except only the highest use rate for each treatment was included. Herbicides were applied as previously described except a 2 nozzle handheld sprayer boom was used since the treated area was a $1-\mathrm{m}^{2}$ quadrat centered on each western prairie fringed orchid. Each of the 4 treatments was randomly assigned to 12 flowering (replicates) western prairie fringed orchids for a total of 48 western prairie fringed orchids in the study. The herbicides were applied in midSeptember 1998. This timing was optimal for leafy spurge control with these herbicides and allowed the western prairie fringed orchid to complete its life cycle; most of the treated western prairie fringed orchids had disseminated their seeds and were senescent.
Western prairie fringed orchid counts were conducted during peak flowering in July 1999. A $1-\mathrm{m}^{2}$ quadrat was centered on each permanently marked western prairie fringed orchid. Western prairie fringed orchids inside the quadrat were counted and recorded. Herbicide treatment effects on western prairie fringed orchids were tested using ANOVA for a completely random experimental design (SPSS 1994). Means were separated using Duncan's Multiple Range Test and considered significant at $\mathrm{P}<0.05$.

Above-average precipitation during the study and plentiful rainfall throughout the 1999 growing season resulted in a high water table. Study western prairie fringed orchids were under water in September 1999 at the time that second-year herbicide treatments were to be applied; consequently the study was terminated.

\section{Soil Seedbank Study}

Soil cores for seedbank analysis were taken from the herbicide efficacy plots in May and October 1998. Each plot was subdivided into $2,1.5$ - by $9.1-\mathrm{m}$ subsections with 5 soil cores sampled centrally at 1.5-m intervals down the long axis of each subsection. Soil cores were taken to a depth of $2.5 \mathrm{~cm}$ using a standard golf-cup cutter (10 cm diameter). Soils were composited by subsection, dried at $35^{\circ} \mathrm{C}$ for 7 days and placed in a refrigerator at $3^{\circ} \mathrm{C}$ prior to germination.

Greenhouse germination procedures followed those outlined by Ter Heerdt et al. (1996). The soil cores were washed through coarse $(4 \mathrm{~mm})$ and fine $(2 \mathrm{~mm})$ sieves to remove roots, pebbles, sand, clay, etc. Each concentrated sample was then spread from 3 to $5 \mathrm{~mm}$ thick in 28by $56-\mathrm{cm}$ trays on a mixture of steam-sterilized soil and commercial potting mix topped by a 4-mm thick layer of sterile sil- ica sand. Trays were watered daily, temperature was maintained between 20 and $28^{\circ} \mathrm{C}$, and natural and supplemental light at $450: \mu \mathrm{Em}^{-2}$ second $^{-1}$ resulted in 16 hours of available light. Following germination, seedlings were identified, counted, and removed. Seedlings that could not be identified were transplanted to larger pots for continuation of growth until a positive identification could be made. Trays were evaluated until no seedlings emerged for at least 1 week, resulting in an approximately 16-week germination period.

Scientific names of plants germinated from soil cores follow that of the Flora of the Great Plains (Great Plains Flora Association 1986). Coefficients of conservatism were assigned to plant species based on an assessment provided by the Northern Great Plains Floristic Quality Assessment Panel (2001). Coefficients of Conservatism range from a value of 0 for plant species that flourish in highly disturbed habitats to 10 for species indicative of undisturbed, natural habitats.

Soil seedbank composition was analyzed using the ANOVA procedure for a randomized complete block design replicated 4 times (SPSS 1994). Means were separated using Duncan's Multiple Range Test and considered significant at $\mathrm{P}<0.05$.

\section{Results and Discussion}

\section{Leafy Spurge Herbicide Trial}

Foliar canopy cover of leafy spurge 10 and 22 months after first treatment was reduced by quinclorac and imazapic following 2 annual fall-applied treatments regardless of application rate (Table 1). Glyphosate plus 2,4-D did not consistently reduce leafy spurge canopy cover. Grass canopy cover 10 months after first treatment increased where imazapic at $70 \mathrm{~g}$ ae

Table 1. Percent canopy cover following 2 annual fall-applied herbicide treatments for leafy spurge control on the Sheyenne National Grassland, North Dakota.

\begin{tabular}{|c|c|c|c|c|c|c|c|}
\hline \multirow[b]{3}{*}{ Treatment $^{1}$} & \multirow[b]{3}{*}{ Rate } & \multicolumn{6}{|c|}{ Plant class $^{2}$} \\
\hline & & \multicolumn{3}{|c|}{$10 \mathrm{MAFT}^{3}$} & \multicolumn{3}{|c|}{$22 \mathrm{MAFT}^{3}$} \\
\hline & & $\begin{array}{l}\text { Leafy } \\
\text { spurge }\end{array}$ & Graminoids & $\begin{array}{c}\text { Native } \\
\text { forbs }\end{array}$ & $\begin{array}{l}\text { Leafy } \\
\text { spurge }\end{array}$ & Graminoids & $\begin{array}{c}\text { Native } \\
\text { forbs }\end{array}$ \\
\hline & $\left(\mathrm{g} \mathrm{ae} \mathrm{ha}^{-1}\right)$ & ------- & (\%) ------ & 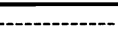 & ------- & (\%) --- & - \\
\hline Control & & $13 \mathrm{~cd}$ & $31 \mathrm{ab}$ & $16 \mathrm{ab}$ & $18 \mathrm{~b}$ & $33 \mathrm{~b}$ & $4 \mathrm{a}$ \\
\hline Glyphosate +2,4-D & $220+330$ & $8 \mathrm{bc}$ & $33 \mathrm{abc}$ & $8 \mathrm{a}$ & $7 \mathrm{a}$ & $50 \mathrm{c}$ & $4 \mathrm{a}$ \\
\hline Glyphosate $+2,4,-\mathrm{D}$ & $440+670$ & $18 \mathrm{~d}$ & $23 \mathrm{a}$ & $9 \mathrm{a}$ & $19 \mathrm{~b}$ & $18 \mathrm{a}$ & $6 a$ \\
\hline Imazapic $+\mathrm{MSO}^{3}+28 \% \mathrm{~N}^{3}$ & 70 & $4 \mathrm{ab}$ & $48 \mathrm{~d}$ & $9 \mathrm{a}$ & $4 \mathrm{a}$ & $51 \mathrm{c}$ & $6 a$ \\
\hline Imazapic $+\mathrm{MSO}^{3}+28 \% \mathrm{~N}^{3}$ & 140 & $2 a$ & 39 bcd & $13 a b$ & $2 \mathrm{a}$ & $48 \mathrm{c}$ & $6 a$ \\
\hline Quinclorac + $\mathrm{MSO}^{3}$ & 880 & $2 \mathrm{ab}$ & $45 \mathrm{~cd}$ & $20 \mathrm{ab}$ & $3 a$ & $60 \mathrm{~d}$ & $5 \mathrm{a}$ \\
\hline Quinclorac + $\mathrm{MSO}^{3}$ & 1100 & $1 \mathrm{a}$ & $31 \mathrm{ab}$ & $23 \mathrm{~b}$ & $1 \mathrm{a}$ & $64 d$ & $5 \mathrm{a}$ \\
\hline
\end{tabular}

Applied in mid-September in 1997 and 1998 to the same plots.

${ }^{2}$ Means in columns followed by a different letter differ $(\mathrm{P}<0.05)$.

${ }^{3}$ Abbreviations: MAFT, months after first treatment; MSO, methylated seed oil at 2.3 liters ha ${ }^{-1} ; 28 \% \mathrm{~N}$, urea-ammonium nitrate fertilizer at 2.3 liters ha ${ }^{-1}$. 
$\mathrm{ha}^{-1}$ and quinclorac at $880 \mathrm{~g}$ ae ha $^{-1}$ were applied. Grass foliar cover 22 months after first treatment increased compared to the control for all treatments evaluated, except glyphosate plus 2,4-D at 440 plus $670 \mathrm{~g}$ $\mathrm{ha}^{-1}$. The reduced grass cover from the high rate glyphosate plus 2,4-D treatment was due to herbicide injury, which has been documented in prior studies in the northern Great Plains (Lym and Kirby 1991, Lym et al. 1991). Native forb cover 10 and 22 months after first treatment was not altered regardless of treatment.

Leafy spurge stem density was reduced following single and repeated quinclorac and imazapic treatments at both rates evaluated (Table 2). Leafy spurge stem density 10 months after first treatment averaged 0 to 3 stems $\mathrm{m}^{-2}$ for quinclorac and imazapic treatments compared to 40 stems $\mathrm{m}^{-2}$ in the untreated control. Leafy spurge stem density 22 months after first treatment increased slightly to 5 and 19 stems $\mathrm{m}^{-2}$, but the stem count nearly doubled in the untreated control to 79 stems $\mathrm{m}^{-2}$. Generally, glyphosate plus 2,4-D did not reduce leafy spurge stem density compared to the control.

Leafy spurge yield 23 months after first treatment was reduced following 2 annual treatments of quinclorac and imazapic, regardless of application rate (Table 3 ). In contrast, grass yield following 2 annual treatments of quinclorac and imazapic significantly increased compared to the untreated control but not with glyphosate plus 2,4-D. Yields of grass-likes, forbs and other plant species did not differ from the untreated control.

The response of leafy spurge and grass to herbicides was similar to previous reports. Kuehl and Lym (1997) and Masters et al. (1998) reported good leafy spurge control with fall-applied quinclorac treatments without adverse affects on forage yields. Masters et al. (1998) and Markle and Lym (2001) reported similar control of leafy spurge with imazapic to the present study with little to no loss in herbage production. However, imazapic has been injurious to grasses when a fall treatment was followed by a spring treatment compared to a single fall treatment (Masters et al. 1998).

\section{Herbicide Effect on Western Prairie Fringed Orchid Reoccurrence}

Three fall-applied herbicide treatments did not reduce reoccurrence of western prairie fringed orchid the first year following treatment (Fig. 1). Western prairie fringed orchids reoccurred in $83 \%$ of the plots treated with quinclorac, $60 \%$ for both
Table 2. Leafy spurge stem density following 2 annual fall-applied herbicide treatments on the Sheyenne National Grassland, North Dakota.

\begin{tabular}{|c|c|c|c|}
\hline Treatment $^{1}$ & Rate & $10 \mathrm{MAFT}^{2,3}$ & $22 \mathrm{MAFT}^{2,3}$ \\
\hline & $--\left(\mathrm{g}\right.$ ae ha $\left.{ }^{-1}\right)-$ & \multicolumn{2}{|c|}{ - no. $\mathrm{m}^{-2}$ ) - } \\
\hline Control & & $40 \mathrm{c}$ & $79 \mathrm{~b}$ \\
\hline Glyphosate + 2,4-D & $220+330$ & $35 \mathrm{c}$ & $75 \mathrm{~b}$ \\
\hline Glyphosate + 2,4-D & $440+670$ & $20 \mathrm{~b}$ & $74 \mathrm{~b}$ \\
\hline Imazapic $+\mathrm{MSO}^{3}+28 \% \mathrm{~N}^{3}$ & 70 & $2 \mathrm{a}$ & $19 \mathrm{a}$ \\
\hline Imazapic $+\mathrm{MSO}^{3}+28 \% \mathrm{~N}^{3}$ & 140 & $0 \mathrm{a}$ & $6 a$ \\
\hline Quinclorac + $\mathrm{MSO}^{3}$ & 880 & $3 \mathrm{a}$ & $16 \mathrm{a}$ \\
\hline Quinclorac + $\mathrm{MSO}^{3}$ & 1100 & $0 \mathrm{a}$ & $5 \mathrm{a}$ \\
\hline
\end{tabular}

Applied in mid-September in 1997 and 1998 to the same plots.

${ }^{2}$ Means in columns followed by a different letter differ $(\mathrm{P}<0.05)$.

${ }^{3}$ Abbreviations: MAFT, months after first treatment; MSO, methylated seed oil at 2.3 liters ha ${ }^{-1} ; 28 \% \mathrm{~N}$, urea-ammonium nitrate fertilizer at 2.3 liters ha ${ }^{-1}$. the imazapic and glyphosate plus 2,4-D treatments, and $50 \%$ of the untreated plots. These levels of reoccurrence of untreated western prairie fringed orchid are similar to the previous report that $55 \%$ of permanently marked flowering western prairie fringed orchid in grazed and ungrazed pastures on the Sheyenne National Grassland reappeared the year following marking (Sieg and King 1995). Similarly, western prairie fringed orchid densities 1 year after treatment were not reduced on treated plots relative to control plots (Fig. 2). Western prairie fringed orchid densities averaged $1.9,1.3$, and 0.9 plants $\mathrm{m}^{-2}$ in the plots treated with quinclorac, glyphosate plus 2,4-D and imazapic, respectively, compared to 1.1 western prairie fringed orchids $\mathrm{m}^{-2}$ in the untreated plots.

We attribute these results mostly to the timing of herbicide treatments relative to the phenology of the western prairie fringed orchid. The western prairie fringed orchids had completed their life cycles and were senescent when the herbicides were applied, so little imazapic and quinchlorac absorption and translocation into the western prairie fringed orchid roots was expected. Also some evidence suggests that quinclorac and imazapic are more likely to damage dicots such as leafy spurge than they are to damage monocots such as the western prairie fringed orchid (Lym et al. 1991, Kuehl and Lym 1997, Masters et al. 1998, Markle and Lym 2001). Cover of grasses was reduced by most of the herbicide treatments relative to the control, but grass production 23 months after first treatment in the imazapic and quinclorac treatments was higher compared to the untreated plots (Table 3 ). In contrast, this study and others (Lym and Kirby 1991, Lym et al. 1991) document that glyphosate treatments may reduce grass production.

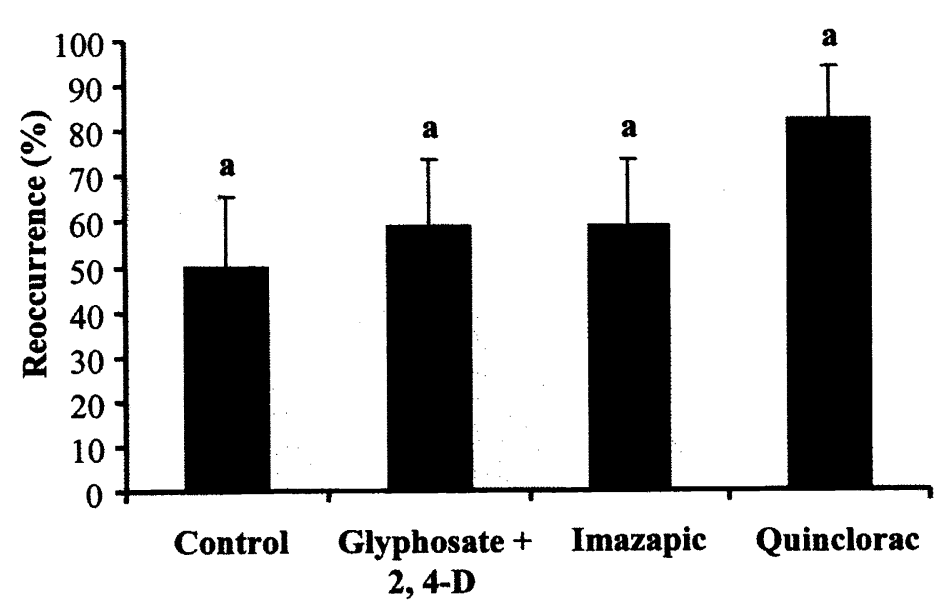

\section{Herbicide treatments}

Fig. 1. Effect of fall-applied herbicides on reoccurrence of western prairie fringed orchids the season following treatment on the Sheyenne National Grassland, N.D. Herbicide rates were glyphosate plus 2,4-D at 440 plus $670 \mathrm{~g}$ ae ha $^{-1}$, imazapic at $150 \mathrm{~g}^{\mathrm{ae} \mathrm{ha}} \mathrm{h}^{-1}$ plus methylated seed oil at 2.3 liters $\mathrm{ha}^{-1}$, and quinchlorac at $1100 \mathrm{~g} \mathrm{ae} \mathrm{ha}^{-1}$ plus methylated seed oil at 2.3 liters ha ${ }^{-1}$. Percent reoccurrence did not differ $(P>0.05)$ among treatments. 
Table 3. Herbaceous yields in August 1999, 23 months after the first treatment, following 2 annual fall-applied herbicide treatments for leafy spurge control on the Sheyenne National Grassland, North Dakota.

\begin{tabular}{|c|c|c|c|c|c|c|}
\hline Treatment $^{1}$ & Rate & $\begin{array}{l}\text { Leafy } \\
\text { spurge }\end{array}$ & Grass & $\begin{array}{c}\text { ant class } \\
\text { Grass- } \\
\text { like }\end{array}$ & $\begin{array}{l}\text { Native } \\
\text { forbs }\end{array}$ & Other \\
\hline & $\left(\mathrm{g}\right.$ ae ha $\left.{ }^{-1}\right)$ & -----. & - & $-\left(\mathrm{g} \mathrm{m}^{-2}\right)$ & & ---- \\
\hline Control & & $101 \mathrm{~b}$ & $120 \mathrm{a}$ & $9 \mathrm{ab}$ & $38 \mathrm{ab}$ & $63 \pm 6.4 \mathrm{a}$ \\
\hline Glyphosate + 2,4-D & $220+330$ & $75 \mathrm{~b}$ & $86 \mathrm{a}$ & $3 \mathrm{a}$ & $47 \mathrm{~b}$ & $34 \pm 2.4 \mathrm{a}$ \\
\hline Glyphosate $+2,4-\mathrm{D}$ & $440+670$ & $70 \mathrm{~b}$ & $79 \mathrm{a}$ & $5 \mathrm{a}$ & $30 \mathrm{ab}$ & $65 \pm 6.9 \mathrm{a}$ \\
\hline Imazapic $+\mathrm{MSO}^{3}+28 \% \mathrm{~N}^{3}$ & 70 & $9 \mathrm{a}$ & $172 \mathrm{c}$ & $9 \mathrm{ab}$ & $26 \mathrm{ab}$ & $56 \pm 6.0 \mathrm{a}$ \\
\hline Imazapic $+\mathrm{MSO}^{3}+28 \% \mathrm{~N}^{3}$ & 140 & $2 a$ & $224 d$ & $1 \mathrm{a}$ & $34 \mathrm{ab}$ & $29 \pm 4.9 \mathrm{a}$ \\
\hline Quinclorac $+\mathrm{MSO}^{3}$ & 880 & $13 \mathrm{a}$ & $160 \mathrm{bc}$ & $25 \mathrm{~b}$ & $10 \mathrm{a}$ & $30 \pm 3.7 \mathrm{a}$ \\
\hline Quinclorac + $\mathrm{MSO}^{3}$ & 1100 & $4 \mathrm{a}$ & $200 \mathrm{~cd}$ & $15 \mathrm{ab}$ & $33 \mathrm{ab}$ & $29 \pm 2.4 \mathrm{a}$ \\
\hline
\end{tabular}

Applied in mid-September in 1997 and 1998 to the same plots.

${ }^{2}$ Means in columns followed by a different letter differ $(\mathrm{P}<0.05)$.

${ }^{3}$ Abbreviations: MSO, methylated seed oil at 2.3 liters ha ${ }^{-1} ; 28 \% \mathrm{~N}$, urea-ammonium nitrate fertilizer at 2.3 liters ha ${ }^{-1}$.

Finally, some evidence exists that herbicides may reduce interspecific competition, and thus may encourage the western prairie fringed orchid to germinate and develop when adequate soil moisture is present. Several studies have documented episodic flowering and seed production in the western prairie fringed orchid that is associated with adequate soil moisture (Sieg and King 1995), and others have speculated on the importance of disturbances such as fire or grazing for stimulating western prairie fringed orchid growth (Bowles 1983).

\section{Soil Seedbank Study}

A total of 53 genera or species were identified in spring and fall soil seedbank cores (Table 4). Of these, $60 \%$ were considered early seral species indicative of disturbed tallgrass prairie. Grasses that germinated, which are indicative of disturbance were the annual species, common witchgrass (Panicum capillare L.) and yellow foxtail (Setaria glauca (L.) Beauv.), and perennial species, redtop (Agrostis stolonifera L.) and Kentucky bluegrass (Poa pratensis L.). Thirty-six genera or species of forbs were identified, of which less than $50 \%$ were perennial and nearly $33 \%$ were introduced species. Introduced species included common lambsquarters (Chenopodium album L.), Canada thistle (Cirsium arvense (L.) scop.), leafy spurge, kochia (Kochia scoparia (L.) Schrad.), prickly lettuce (Lactuca serriola L.), black medic (Medicago lupulina L.), sweetclover (Melilotus spp.), field thistle (Sonchus arvensis L.) and field pennycress (Thlapsi arvense L.).

Fourteen grass genera or species were present, of which approximately $80 \%$ were perennial and native species of the tallgrass prairie (Table 4). Native tallgrass prairie species germinating from soil cores includ- ed big bluestem, sideoats grama (Bouteloua curtipendula (Michx) Torr.), prairie junegrass (Koeleria pyramidata (Lam.) Beauv.), little bluestem, sand dropseed (Sporobolus cryptandrus (Torr.) A. Gray), needleandthread (Stipa comata Trin. \& Rupr.) and green needlegrass (Stipa viridula Trin.). Carex, Juncus and Typha species were also identified in soil cores.

There was an abundance of viable seed in the soil seedbank of the study area (Table 5). The average seedling density to a $2.5 \mathrm{~cm}$ depth ranged from 1570 to 2090 seedlings $\mathrm{m}^{-2}$. Of this, $38 \%$ to over $50 \%$ were leafy spurge seedlings. Perennial grasses only comprised an average of $4 \%$ of total seedlings in the samples. Total native perennial species, i.e., grasses, forbs and Carex spp., averaged $18 \%$, while early seral and invasive species such as leafy spurge, introduced grasses, Poa spp., forbs and others totaled $82 \%$ of all seedlings in the samples. Thus, for every square meter of soil surface, approximately 1400 early seral and invasive species seeds and propagules could potentially germinate and cover the site. Based on these findings, a sustained weed management program would be needed to successfully revegetate the site upon which this study was conducted following control of leafy spurge.

\section{Conclusions}

Quinclorac and imazapic applied in consecutive falls decreased leafy spurge foliar cover, density and yield. Herbaceous yields, other than leafy spurge, were not reduced and generally were stimulated following quinclorac and imazapic treatment. Fall-applied glyphosate plus 2,4-D did not control leafy spurge or result in increased herbaceous yield.

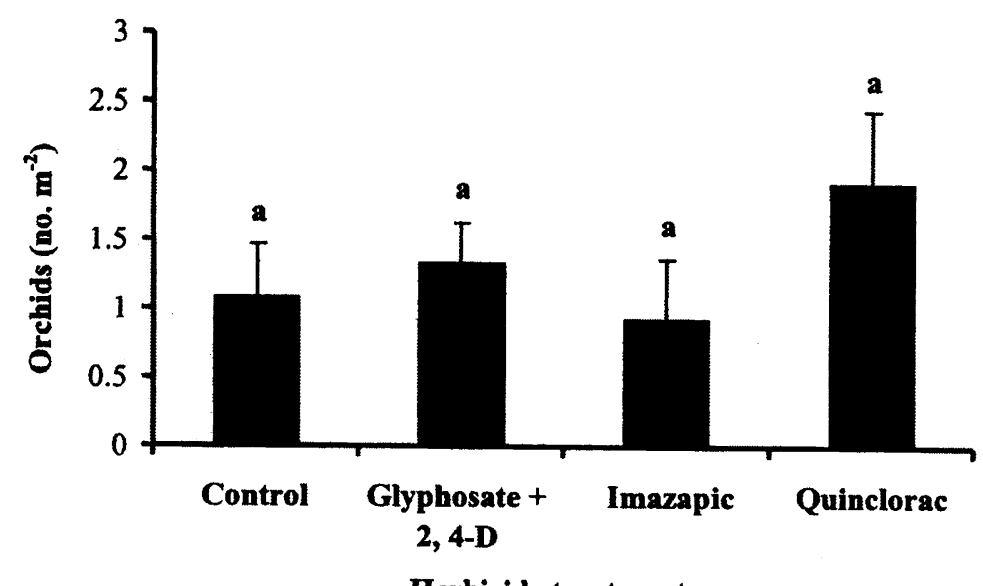

Fig. 2. Average density of western prairie fringed orchids reappearing in herbicide-treated areas the season following treatment on the Sheyenne National Grassland, N.D. Herbicide rates were glyphosate plus 2,4-D at 440 plus $670 \mathrm{~g} \mathrm{ae} \mathrm{ha}^{-1}$, imazapic at $140 \mathrm{~g}^{2} \mathrm{ae} \mathrm{h}^{-1}$ plus methylated seed oil at 2.3 liters ha- ${ }^{-1}$ and quinchlorac at $1100 \mathrm{~g}^{2} \mathrm{ha}^{-1}$ plus methylated seed oil at 2.3 liters $h^{-1}$. Densities did not differ $(P>0.05)$ among treatments. 
Table 4. Scientific name, common name, season encountered, life form, origin, and coefficient of conservatism of plant species identified on herbicide treatments for leafy spurge control in southeastern North Dakota.

\begin{tabular}{|c|c|c|c|c|c|}
\hline Scientific name ${ }^{1}$ & Common name & Season $^{2}$ & $\begin{array}{l}\text { Life } \\
\text { form }^{3}\end{array}$ & Origin $^{4}$ & $\begin{array}{l}\text { Coefficient of } \\
\text { conservatism }^{5}\end{array}$ \\
\hline \multicolumn{6}{|l|}{ Forb species } \\
\hline Amaranthus retroflexus $\mathrm{L}$. & Rough pigweed & Both & A & $\mathrm{N}$ & 0 \\
\hline Ambrosia artemisiifolia $\mathrm{L}$. & Common ragweed & Fall & A & $\mathrm{N}$ & 0 \\
\hline Ambrosia psilostachya $\mathrm{DC}$ & Western ragweed & Spring & $\mathrm{P}$ & $\mathrm{N}$ & 2 \\
\hline Artemisia dracunculus $\mathrm{L}$. & Green sagewort & Both & $\mathrm{P}$ & $\mathrm{N}$ & 4 \\
\hline Artemisia frigida Willd. & Fringed sage & Both & $\mathrm{P}$ & $\mathrm{N}$ & 4 \\
\hline Artemisia ludoviciana Nutt. & Gray sage, pasture sage & Both & $\mathrm{P}$ & $\mathrm{N}$ & 3 \\
\hline Aster ericoides $\mathrm{L}$. & White aster & Spring & $\mathbf{P}$ & $\mathrm{N}$ & 2 \\
\hline Chenopodium album $\mathrm{L}$. & Common lambsquarters & Spring & A & I & 0 \\
\hline Cirsium arvense (L.) Scop. & Canada thistle & Both & $\mathrm{P}$ & I & 0 \\
\hline Conyza canadensis $(\mathrm{L}$.$) Cronq.$ & Horseweed & Both & A & $\mathrm{N}$ & 0 \\
\hline Epilobium ciliatum Ref. & Willow herb & Spring & $\mathbf{P}$ & $\mathrm{N}$ & 3 \\
\hline Erigeron philadelphicus $\mathrm{L}$. & Philadelphia fleabane & Spring & $\mathrm{B}$ & $\mathrm{N}$ & 2 \\
\hline \multicolumn{6}{|l|}{ Muhl. ex Willd. } \\
\hline Erysimum asperum (Nutt.) DC & Western wallflower & Both & B & $\mathrm{N}$ & 3 \\
\hline Euphorbia esula L. & Leafy spurge & Both & $\mathrm{P}$ & I & 0 \\
\hline Euphorbia glyptosperma Englem. & Ridge seeded spurge & Both & A & $\mathrm{N}$ & 0 \\
\hline Fragaria virginiana Duchn. & Wild strawberry & Both & $\mathrm{P}$ & $\mathrm{N}$ & 4 \\
\hline Geranium spp. & Geranium spp. & Both & $\mathrm{A}, \mathrm{P}$ & $\mathrm{I}, \mathrm{N}$ & - \\
\hline Kochia scoparia (L.) Schrad. & Kochia & Fall & A & I & 0 \\
\hline Lactuca serriola $\mathrm{L}$. & Prickly lettuce & Fall & A & I & 0 \\
\hline Lepidium densiflorum Schrad. & Peppergrass & Both & A & $\mathrm{N}$ & 0 \\
\hline Liatris spp. & Liatris spp. & Spring & $\mathrm{P}$ & $\mathrm{N}$ & - \\
\hline Lycopus asper Greene & Rough bugleweed & Both & $\mathrm{P}$ & $\mathrm{N}$ & 4 \\
\hline Medicago lupulina $\mathrm{L}$. & Black medic & Both & A & I & 0 \\
\hline Melilotus spp. & Sweetclover & Both & B & I & 0 \\
\hline Oenothera biennis $\mathrm{L}$. & Common evening primrose & Both & B & $\mathrm{N}$ & 0 \\
\hline Oxalis stricta $\mathrm{L}$ & Yellow wood sorrel & Both & $\mathrm{P}$ & $\mathrm{N}$ & 0 \\
\hline Physalis virginiana $\mathrm{P}$. Mill. & Virginia groundcherry & Fall & $\mathrm{P}$ & $\mathrm{N}$ & 4 \\
\hline Rudbeckia hirta $\mathrm{L}$. & Black eyed susan & Both & B & $\mathrm{N}$ & 5 \\
\hline Salsola iberica Senn. \& Pau & Russian thistle & Spring & A & I & 0 \\
\hline Solanum ptycanthum Dun. ex CD & Black nightshade & Both & A & $\mathrm{N}$ & 0 \\
\hline Solidago gigantea Ait. & Late goldenrod & Fall & $\mathrm{P}$ & $\mathrm{N}$ & 4 \\
\hline Solidago missouriensis Nutt. & Prairie goldenrod & Spring & $\mathrm{P}$ & $\mathrm{N}$ & 5 \\
\hline Sonchus arvensis $\mathrm{L}$. & Field thistle & Both & $\mathrm{P}$ & I & 0 \\
\hline Thlaspi arvense $\mathrm{L}$. & Field pennycress & Both & A & I & 0 \\
\hline Urtica dioica $\mathrm{L}$. & Stinging nettle & Fall & $P$ & $\mathrm{~N}$ & 0 \\
\hline \multicolumn{6}{|l|}{ Grass species } \\
\hline Agrostis stolonifera $\mathrm{L}$. & Redtop & Both & $\mathrm{P}$ & I & 0 \\
\hline Andropogon gerardii Vitman & Big bluestem & Both & $\mathrm{P}$ & $\mathrm{N}$ & 5 \\
\hline $\begin{array}{l}\text { Bouteloua curtipendula } \\
\text { (Michx) Torr. }\end{array}$ & Sideoats grama & Spring & $\mathrm{P}$ & $\mathrm{N}$ & 5 \\
\hline $\begin{array}{l}\text { Dichanthelium wilcoxianum } \\
\text { (Vasey) Freckmann }\end{array}$ & Wilcox dichanthelium & Both & $\mathrm{P}$ & $\mathrm{N}$ & 8 \\
\hline $\begin{array}{l}\text { Koeleria pyramidata } \\
\text { (Lam.) Beauv. }\end{array}$ & Prairie junegrass & Spring & $P$ & $\mathrm{~N}$ & 7 \\
\hline $\begin{array}{l}\text { Muhlenbergia racemosa } \\
\text { (Michx.) B.S.P. }\end{array}$ & Marsh muhly & Spring & $\mathrm{P}$ & $\mathrm{N}$ & 4 \\
\hline Panicum capillare $\mathrm{L}$. & Common witchgrass & Both & A & $\mathrm{N}$ & 0 \\
\hline Poa compressa $\mathrm{L}$. & Canada bluegrass & Spring & $\mathbf{P}$ & I & 0 \\
\hline Poa pratensis $\mathrm{L}$. & Kentucky bluegrass & Fall & $\mathrm{P}$ & I & 0 \\
\hline $\begin{array}{l}\text { Schizarchyrium scoparium } \\
\text { (Michx.) Nash }\end{array}$ & Little bluestem & Both & $\mathrm{P}$ & $\mathrm{N}$ & 6 \\
\hline Setaria glauca (L.) Beauv. & Yellow foxtail & Spring & A & I & 0 \\
\hline $\begin{array}{l}\text { Sporobolus cryptandrus } \\
\text { (Torr.) A. Gray }\end{array}$ & Sand dropseed & Spring & $\mathrm{P}$ & $\mathrm{N}$ & 6 \\
\hline Stipa comata Trin. \& Rupr. & Needleandthread & Spring & $P$ & $\mathrm{~N}$ & 6 \\
\hline Stipa viridula Trin. & Green needlegrass & Spring & $P$ & $\mathrm{~N}$ & 5 \\
\hline \multicolumn{6}{|l|}{ Other } \\
\hline Carex spp. & Sedge spp. & Both & $\mathrm{P}$ & $\mathrm{N}$ & - \\
\hline Juncus spp. & Rush spp. & Both & $\mathrm{P}$ & $\mathrm{N}$ & - \\
\hline Typha spp. & Cattail spp. & Both & $\mathrm{P}$ & $\mathrm{I}, \mathrm{N}$ & - \\
\hline
\end{tabular}

${ }^{1}$ Scientific names follow the nomenclature of the Flora of the Great Plains (Great Plains Flora Association 1986).

${ }^{2}$ Indicates if the seedlings were encountered in the spring, fall, or both sample periods.

${ }^{3}$ Life-form - P, perennial; A, annual; B, biennial.

${ }^{4}$ Origin - N, native; I, introduced.

${ }^{5} \mathrm{~A}$ coefficient value of 0 is indicative of species that flourish in highly disturbed habitats, while higher values (to 10 ) are assigned to species from undisturbed, natural areas (The Northern Great Plains Floristic Quality Assessment Panel 2001). 
Table 5. Combined spring and fall soil seedbank composition for 6 herbicide treatments for leafy spurge control in southeastern North Dakota.

\begin{tabular}{|c|c|c|c|c|c|c|c|c|c|c|}
\hline \multirow[b]{2}{*}{ Treatment ${ }^{1}$} & \multirow[b]{2}{*}{ Rate } & \multirow[b]{2}{*}{$\begin{array}{l}\text { Seedling } \\
\text { density }^{2}\end{array}$} & \multicolumn{8}{|c|}{ Class $^{3}$} \\
\hline & & & $\begin{array}{l}\text { Leafy } \\
\text { spurge }\end{array}$ & $\begin{array}{l}\text { Perennial } \\
\text { native } \\
\text { grasses }\end{array}$ & $\begin{array}{l}\text { Poa } \\
\text { spp. }\end{array}$ & $\begin{array}{l}\text { Native } \\
\text { forbs }\end{array}$ & $\begin{array}{l}\text { Introduced } \\
\text { forbs }\end{array}$ & Other & $\begin{array}{c}\text { Total } \\
\text { native } \\
\text { perennial } \\
\text { species }^{4}\end{array}$ & $\begin{array}{c}\text { Total } \\
\text { introduced } \\
\text { species }^{5}\end{array}$ \\
\hline & $\left(\mathrm{g}\right.$ ae $\left.\mathrm{ha}^{-1}\right)$ & $\left(\right.$ no. $\left.m^{-2}\right)$ & - & - & - & $(c$ & - & ............. & - & 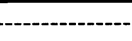 \\
\hline Control & & 2090 & $37.6 \mathrm{a}$ & $4.7 \mathrm{ab}$ & $21.3 \mathrm{a}$ & $10.2 \mathrm{~b}$ & $17.1 \mathrm{~b}$ & $9.1 \mathrm{a}$ & $14.9 \mathrm{a}$ & $38.5 \mathrm{a}$ \\
\hline $\begin{array}{l}\text { Glyphosate + } \\
2,4-\mathrm{D}\end{array}$ & $220+330$ & 1590 & $45.4 \mathrm{ab}$ & $4.8 \mathrm{ab}$ & $28.0 \mathrm{a}$ & $7.2 \mathrm{ab}$ & $7.0 \mathrm{a}$ & $7.6 \mathrm{a}$ & $12.0 \mathrm{a}$ & $35.3 \mathrm{a}$ \\
\hline $\begin{array}{l}\text { Glyphosate + } \\
2,4-\mathrm{D}\end{array}$ & $440+670$ & 1620 & $51.9 \mathrm{~b}$ & $2.7 \mathrm{a}$ & $22.7 \mathrm{a}$ & $6.3 \mathrm{ab}$ & $7.5 \mathrm{a}$ & $8.9 \mathrm{a}$ & $9.1 \mathrm{a}$ & $30.3 \mathrm{a}$ \\
\hline $\begin{array}{l}\text { Imazapic + } \\
\mathrm{MSO}^{6} \\
+28 \% \mathrm{~N}^{6}\end{array}$ & 70 & 1430 & $46.7 \mathrm{ab}$ & $3.5 \mathrm{ab}$ & $23.0 \mathrm{a}$ & $6.4 \mathrm{ab}$ & $8.5 \mathrm{a}$ & $11.9 \mathrm{a}$ & $9.9 \mathrm{a}$ & $31.6 \mathrm{a}$ \\
\hline $\begin{array}{l}\text { Imazapic + } \\
\mathrm{MSO}^{6}+ \\
28 \% \mathrm{~N}^{6}\end{array}$ & 140 & 1770 & $45.7 \mathrm{ab}$ & $3.5 \mathrm{ab}$ & $24.9 \mathrm{a}$ & $5.4 \mathrm{a}$ & $9.4 \mathrm{a}$ & $11.1 \mathrm{a}$ & $8.9 \mathrm{a}$ & $34.5 \mathrm{a}$ \\
\hline $\begin{array}{l}\text { Quinclorac + } \\
\text { MSO }^{6}\end{array}$ & 880 & 1710 & $50.0 \mathrm{ab}$ & $5.9 \mathrm{~b}$ & $23.6 \mathrm{a}$ & $5.3 \mathrm{a}$ & $7.5 \mathrm{a}$ & $7.7 \mathrm{a}$ & $11.3 \mathrm{a}$ & $31.2 \mathrm{a}$ \\
\hline $\begin{array}{l}\text { Quinclorac + } \\
\text { MSO }^{6}\end{array}$ & 1100 & 1770 & 42.9ab & $3.9 \mathrm{ab}$ & $21.7 \mathrm{a}$ & $8.7 a b$ & $13.3 \mathrm{ab}$ & $9.5 \mathrm{a}$ & $12.6 \mathrm{a}$ & $35.2 \mathrm{a}$ \\
\hline
\end{tabular}

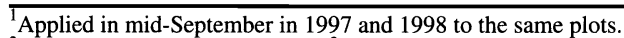

${ }^{2}$ Average number of seedlings $\mathrm{m}^{-2}$ in soil sampled to a $2.5 \mathrm{~cm}$ depth.

${ }^{3}$ Means in a column followed by a different letter differ $(\mathrm{P}<0.05)$.

${ }^{4}$ Includes perennial and native grasses and forbs.

${ }^{5}$ Leafy spurge and Other category are not included in total percentage of introduced species.

${ }^{6} \mathrm{MSO}$, methylated seed oil at 2.3 liters $^{-1} ; 28 \% \mathrm{~N}$, urea-ammonium nitrate fertilizer at 2.3 liters $^{-1} \mathrm{~h}^{-1}$

Single season data on the impact of these herbicides on the western prairie fringed orchid demonstrated no reductions in western prairie fringed orchid reoccurrence or density in treated plots. This result can most likely be attributed to the timing of the herbicide application. In this study, western prairie fringed orchids were sprayed after they were senescent, thus reducing potential translocation in western prairie fringed orchid. Also following senescence, reduction of herbicide absorption into the roots would be expected. Longer term data are needed to fully assess the impact of herbicide treatments on western prairie fringed orchid regrowth, flowering, and seed production.

A total of 53 genera or species were identified in the soil seedbank, of which $60 \%$ were considered early seral species indicative of disturbance. Approximately 1500 to over 2000 seedlings $\mathrm{m}^{-2}$ of soil surface to a $2.5 \mathrm{~cm}$ depth, from seeds and propagules were present in soils from the study site. Over $80 \%$ of the seedlings were early seral species and invasive species including leafy spurge, which comprised over half of these seedlings. Thus, a longterm weed management program will be necessary to successfully revegetate this site even after leafy spurge is controlled. Questions concerning the effect of repeated fall-applied herbicide treatments on the western prairie fringed orchid in a longterm weed management program remain to be answered.

\section{Literature Cited}

Bowles, M.L. 1983. The tallgrass prairie orchids Platanthera leucophaea (Nutt.) Lindl. and Cypripedium candidum Mulh. ex. Willd.: some aspects of their status, biology and ecology and implications toward management. Nat. Areas J. 3:4-37.

Daubenmire, R.F. 1959. A canopy-cover method of vegetational analysis. Northwest Sci. 33:43-66.

Dunn, P.H. 1979. The distribution of leafy spurge and other Euphorbia spp. in the United States. Weed Sci. 27:509-516.

Great Plains Flora Association. 1986. Flora of the Great Plains. University Press of Kansas. Lawrence, Kans. p. 1392.

Kuehl, B.D. and R.G. Lym. 1997. Leafy spurge (Euphorbia esula) control with quinclorac. Weed Technol. 11:265-269.

Lym, R.G. 1998. The biology and integrated management of leafy spurge (Euphorbia esula) on North Dakota rangeland. Weed Technol. 12:367-373.

Lym, R.G. 2000. Leafy spurge (Euphorbia esula) control with glyphosate plus 2,4-D. J. Range Manage. 53:68-72.

Lym, R.G. and D.R. Kirby. 1991. Effect of glyphosate on introduced and native grasses. Weed Technol. 5:421-425.

Lym, R.G., C.G. Messersmith, and R. Zollinger. 2000. Leafy spurge identification and control. North Dakota State Univ. Ext. Serv., Fargo, N.D. 58105. W-765 (R), p. 8.

Lym, R.G., K.G. Beck, P.K. Fay, M. Ferrell, and M. Peterson. 1991. Leafy spurge control with glyphosate plus 2,4-D: a regional research project. Proc. West. Soc. Weed Sci. 44:33-35.
Markle, D.M. and R.G. Lym. 2001. Leafy spurge (Euphorbia esula) control and herbage production with imazapic. Weed Technol. 15:474-480.

Masters, R.H., D.D. Beran, and F. RivasPantoja. 1998. Leafy spurge (Euphorbia esula) response to AC263,222. Weed Technol. 12:602-609.

Mundal, D.A., D.L. Olson, and R.B. Carlson. 2002. The effect of Aphthona spp. flea beetle (Coleoptera:Chrysomelidae) larvae feeding on leafy spurge, Euphorbia esula L., root systems and stem density in North Dakota: 1986-1996. Biol. Control (Submitted).

Northern Great Plains Floristic Quality Assessment Panel, The. 2001. Coefficients of conservation for the vascular flora of the Dakotas and adjacent grasslands. U.S. Geol. Surv., Biolo. Res. Divi., Information and Tech. Rep.USGS/BRD/ITR-2001-0001, p. 32.

Seiler, G.J. and W.T. Barker. 1985. Vascular flora of Ransom, Richland, and Sargent counties, North Dakota. Prairie Nat. 17:193-240.

Selleck, G.W., R.T. Coupland, and C. Frankton. 1962. Leafy spurge in Saskatchewan. Ecol. Monogr. 32:1-29.

Sieg, C.H. and A.J. Bjugstad. 1994. Five years of following the western prairie fringed orchid (Platanthera praeclara) on the Sheyenne National Grassland, North Dakota, p. 141-146. In: R.G. Wickett, P.D. Lewis, A. Woodliffe, and P. Pratt (eds.) Proc. Thirteenth North Amer. Prairie Conf., Windsor, Ontario, Canada. 
Sieg, C.H. and R.M. King. 1995. Influence of environmental factors and preliminary demographic analysis of a threatened orchid, Platanthera praeclara. Amer. Midland Nat. 134:61-77.

SPSS, Inc. 1994. SPSS advanced statistics. 6.1 Chicago, IIl

Ter Heerdt, G.N.J., G.L. Verweij, R.M. Bekker, and J.P. Bakker. 1996. An improved method for seedbank analysis: seedling emergence after removing the soil by sieving. Func. Ecol. 10:144-151.
U.S. Fish and Wildlife Service. 1989. Endangered and threatened wildlife and plants: determination of threatened status for Platanthera leucophaea (eastern prairie fringed orchid) and Platanthera praeclara (western prairie fringed orchid). Federal Register 54:39857-39862.

U.S. Fish and Wildlife Service, 1996. Platanthera praeclara (western prairie fringed orchid) recovery plan. U.S. Fish and Wildlife Service, Ft. Snelling, Minn. p. 101.
Winter, B. 1994. Management of Platanthera praeclara on western Minnesota Nature Conservancy Preserves. Western prairie fringed orchid workshop, Crookston, Minn.

Wolken, P.M., C.H. Sieg, and S.E. Williams. 2001. Quantifying suitable habitat of the threatened western prairie fringed orchid. J. Range Manage. 54:611-616.

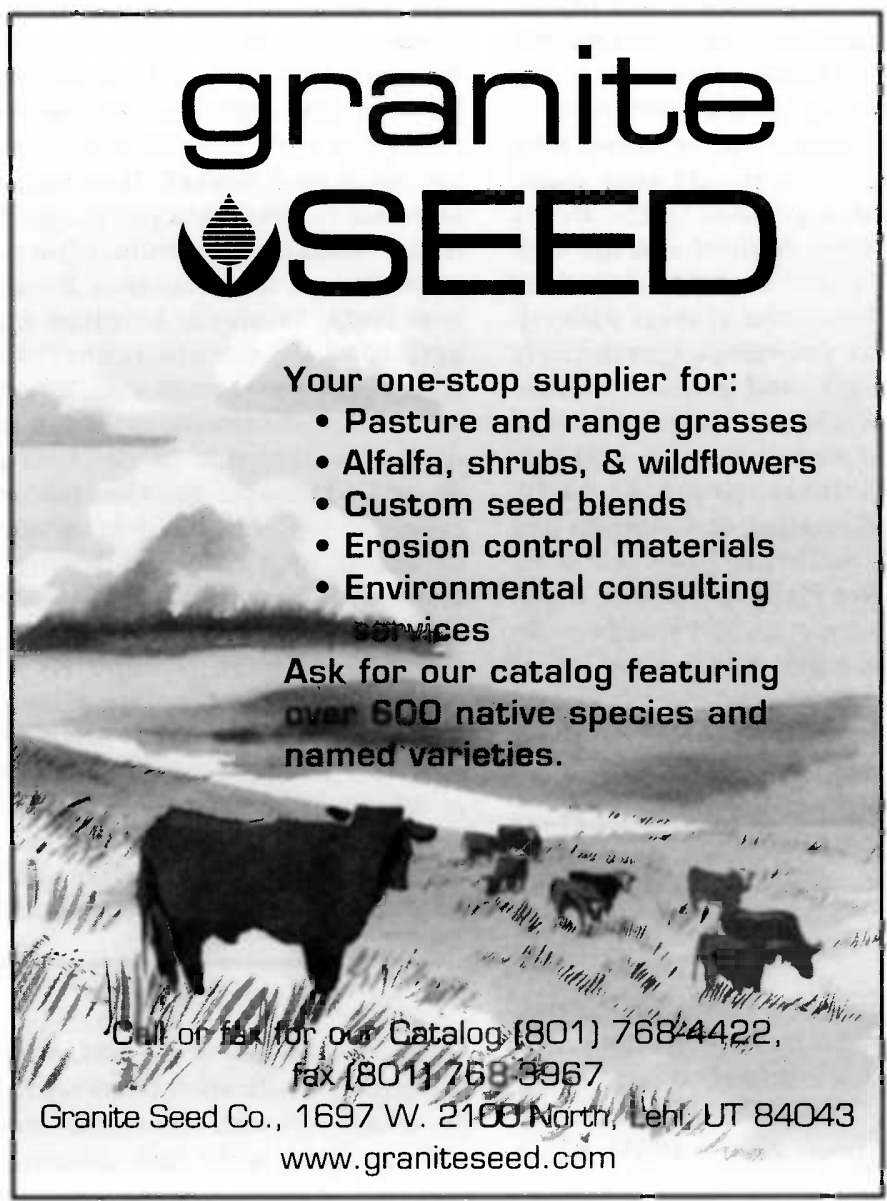

